Profesor dr Milojko Jevtović, dipl. inž.

Elektrotehnički fakultet, Banja Luka

mr Boban Pavlović

kapetan, dipl. inž.

Vojna akademija

Beograd

\section{KONCEPCIJA I KARAKTERISTIKE BUDUĆE GENERACIJE TELEKOMUNIKACIONIH MREŽA}

UDC: $621.39 / 397$

Rezime:

U radu je izložena koncepcija i dat pregled očekivanih i mogućih performansi buduće generacije telekomunikacionih mreža. Opisane su osnovne karakteristike njenih elemenata $i$ navedeni najvažniji protokoli. Takođe, predstavljene su karakteristike multimedijalnih mreža sa stanovišta kvaliteta usluga $i$ analizirani osnovni elementi zaštite mreža, kao i moguće pretnje i odgovarajuće zaštitne protivmere.

Ključne reči: buduća generacija telekomunikacionih mreža - NGN, mrežne arhitekture, kvalitet usluga, multiservisni pristup, multimedijalne komunikacije, zaštita informacija.

\title{
CONCEPT AND CHARACTERISTICS OF THE NEXT GENERATION OF TELECOMMUNICATION NETWORKS
}

\section{Summary:}

In this paper the concept is presented and expected summary and feasible performance of Next Generation Networks are given. Main characteristics of the components of next generation Networks and specified most important protocols are described. Also, characteristics of Quality of Service $(Q o S)$ in multimedia telecommunication networks are presented and major characteristics of network protection are analyzed as well as possible threats and corresponding countermeasures.

Key words: Next Generation Networks, NGN, network architectures, Quality of Service, multi-service access, multimedia communications, information security.

\section{Uvod}

$\mathrm{Na}$ početku novog milenijuma, u razvoju telekomunikacija poseban značaj ima sledeća (buduća) generacija telekomunikacionih mreža (u daljem tekstu NGN, od engleskog naziva Next Generation Networks) od koje se očekuje sledeća velika revolucija u telekomunikacijama [1]. Ova mreža se najčešće definiše kao skup principa i koncepcijskih tehničkih rešenja koja se očekuju od budućih telekomunikacionih mreža. Može se reći da NGN predstavlja koncepcijski kišobran pod kojim se nalazi skup inovacija $i$ promena na putu ka novoj generaciji mreža [1].

Mreže sledeće generacije, zapravo, predstavljaju konvergentne mreže koje obezbeđuju istovremeni prenos podataka i govora, a u kasnijoj fazi i multimedije.

Jedno od najvećih dostignuća predstavlja IP (Internet Protocol) telefonija. Ovom tehnologijom se ostvaruje prenos govora preko mreže koja je prvobitno bila namenjena za prenos podataka. Ova mreža obezbeđuje direktno povezivanje prenosa podataka i govora, pri čemu detekcija tišine i kompresija omogućavaju bolje iskorišćenje propusnog opsega. 
Pred NGN se postavljaju različiti zahtevi (video prenos, prenos saobraćaja u realnom vremenu, podaci visokog prioriteta $\mathrm{i}$ dr.) i nove tehnologije (komutacije, optičke mreže, bežični prenos, satelitski prenos, mreže treće generacije, ...). Nasleđeni problemi iz prethodnog perioda odnose se na javne telefonske mreže, koje su bile projektovane za prenos govornog saobraćaja, ali su danas opterećene velikom količinom podataka koje prenose. Pored toga, postojeće mreže za paketski prenos prvobitno su izgrađene za prenos podataka između računara i bile su neosetljive na kašnjenje. Međutim, danas se od njih zahteva da podrže uslugu prenosa u realnom vremenu, jer podaci se javljaju kao dominantni oblik saobraćaja, i prenos govora u stalnom porastu.

Mreže za prenos podataka još uvek ne pružaju isti nivo QoS i prednosti koje obezbeđuju PSTN (Public Switched Telephone Networks). Ono što je trenutno svojstveno internetu je isti pristup svim korisnicima i podacima, bez obzira na važnost date aplikacije.

Osnovni zahtevi koje NGN mreža mora da ostvari su:

- mogućnost prenosa podataka, govora i video slike preko zajedničke infrastrukture;

- usluge prenosa govora uporedive sa PSTN (po pitanju QoS);

- fleksibilni mehanizmi upravljanja za podršku govornoj komunikaciji i pridruženim servisima podataka, $\mathrm{i}$ snicima.

- dodeljivanje određenog QoS kori-

\section{Neka tehnička rešenja buduće generacije mreža}

Telekomunikacione mreže u narednih nekoliko godina treba da budu restruktuira- ne tako da bi mogle da zadovolje sve veće zahteve za novim uslugama, pre svega za prenos podataka i komunikaciju negovornim porukama. Pri tome se očekuje smanjenje troškova eksploatacije i cene usluga, uz nova investiciona ulaganja. Cilj je realizacija NGN, zasnovanih na paketskom prenosu i komutaciji, uz koje će i dalje egzistirati tradicionalne telefonske mreže bazirane na komutaciji kanala. Drugim rečima, NGN treba da omoguće konvergenciju klasičnih telefonskih, PSTN i paketskih računarskih mreža (internet). Prva je bazirana na komutaciji kola i zasniva se na konstantnoj širini opsega i malim kašnjenjem u prenosu. Internet se zasniva na paketskoj mreži na bazi IP protokola uz pružanje usluge za prenos podataka i govora i formiranje virtuelnih privatnih mreža - VPN. Međutim, danas ova mreža ne obezbeđuje konstantni propusni opseg, konstantno kašnjenje i zahtevani QoS. Perspektiva razvoja mrežne konvergencije u formi NGN prikazana je na slici 1 .

Povezivanje NGN sa postojećim klasičnim mrežama je izvedeno preko medijskih i signalizacionih mrežnih prolaza (media gateway and signaling gateway). Medijski mrežni prolazi obavljaju pretvaranje govornih kanala u pakete podataka i obrnuto, dok je uloga signalizacionih mrežnih prolaza da vrše pretvaranje signalizacije govornih kanala u pakete podataka i obrnuto. Najčešće se vrši pretvaranje signalizacije broj 7 (u daljem tekstu SS7) u jednu od dve vrste signalizacije pri prenosu podataka: H.323 ili MGCP (Media Gateway Control Protocol). Funkciju upravljanja pozivima ima kontrolor medijskih mrežnih prolaza - MGC. Ukoliko u mreži ne postoje MGC kontroleri, potrebno je povezati telefonske centrale koje se nalaze na krajevima paketske mreže enkapsuliranom signalizacijom SS7. 


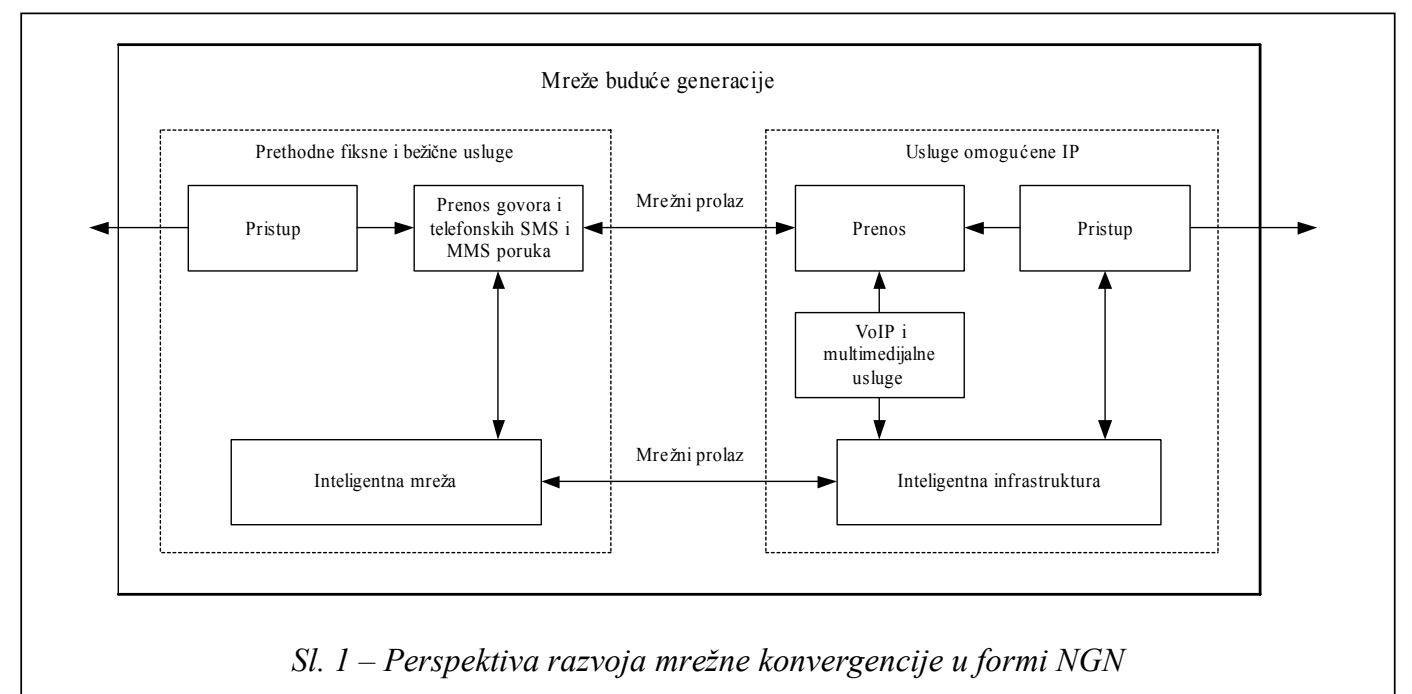

Medijski mrežni prolazi ne služe samo za povezivanje dve telekomunikacione mreže najvišeg nivoa, već i za povezivanje lokalnih IP mreža sa javnom telekomunikacionom mrežom. Na ovaj način lokalnim korisnicima omogućava se korišćenje IP telefonije, pri čemu se kao jezgro i dalje može zadržati postojeća PSTN tehnologija. U lokalnim IP mrežama najčešće egzistiraju protokoli H.323 i SIP (Session Inition Protocol). Slično to- me, postojeći širokopojasni priključci mogu se dograditi IP tehnologijom. S druge strane, ovi priključci već omogućavaju pristup podacima krajnjeg korisnika, što omogućava povezivanje IP terminalne otpreme i pristup klasičnoj telefonskoj centrali preko IP mreže.

Kontrolor NGN ima zadatak da omogući upravljanje pozivima, uslugama, tarifiranje, jednom rečju, sve funkcije koje obavlja klasična telefonska centrala.

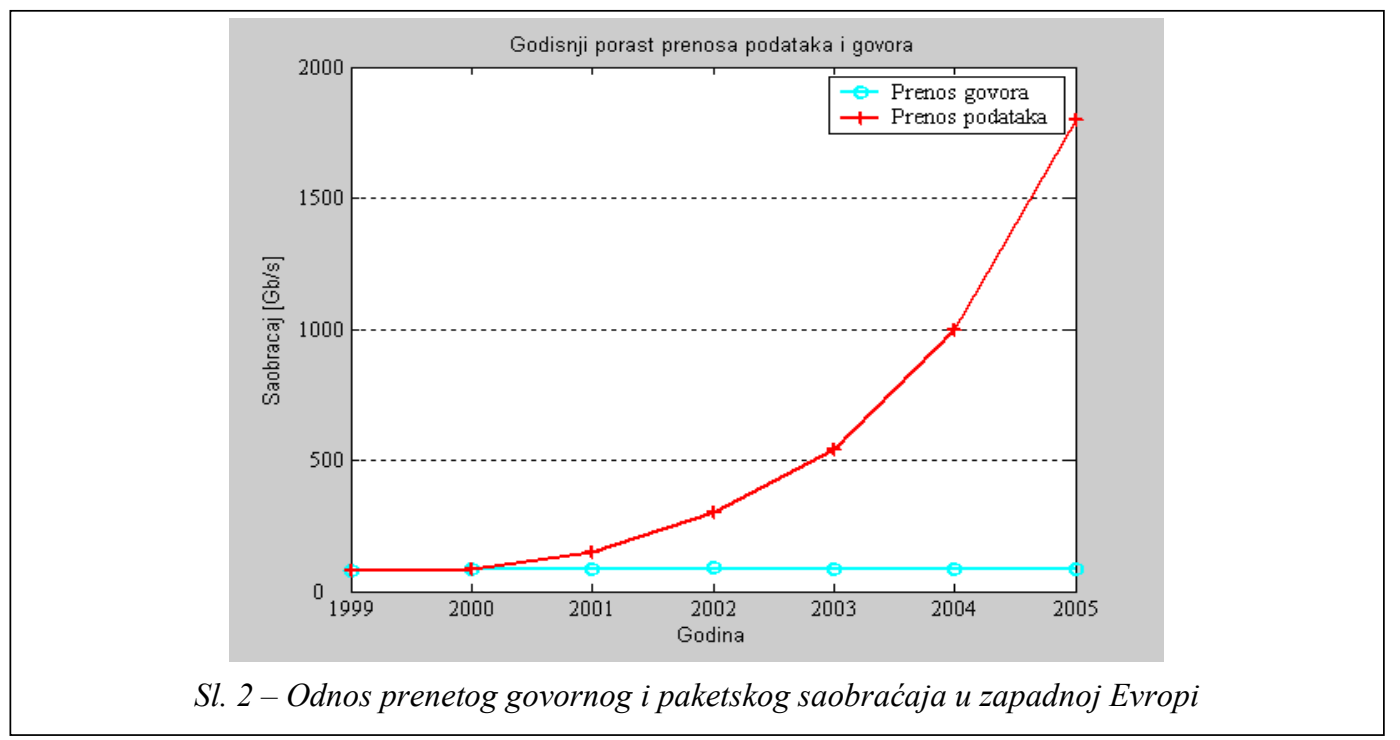




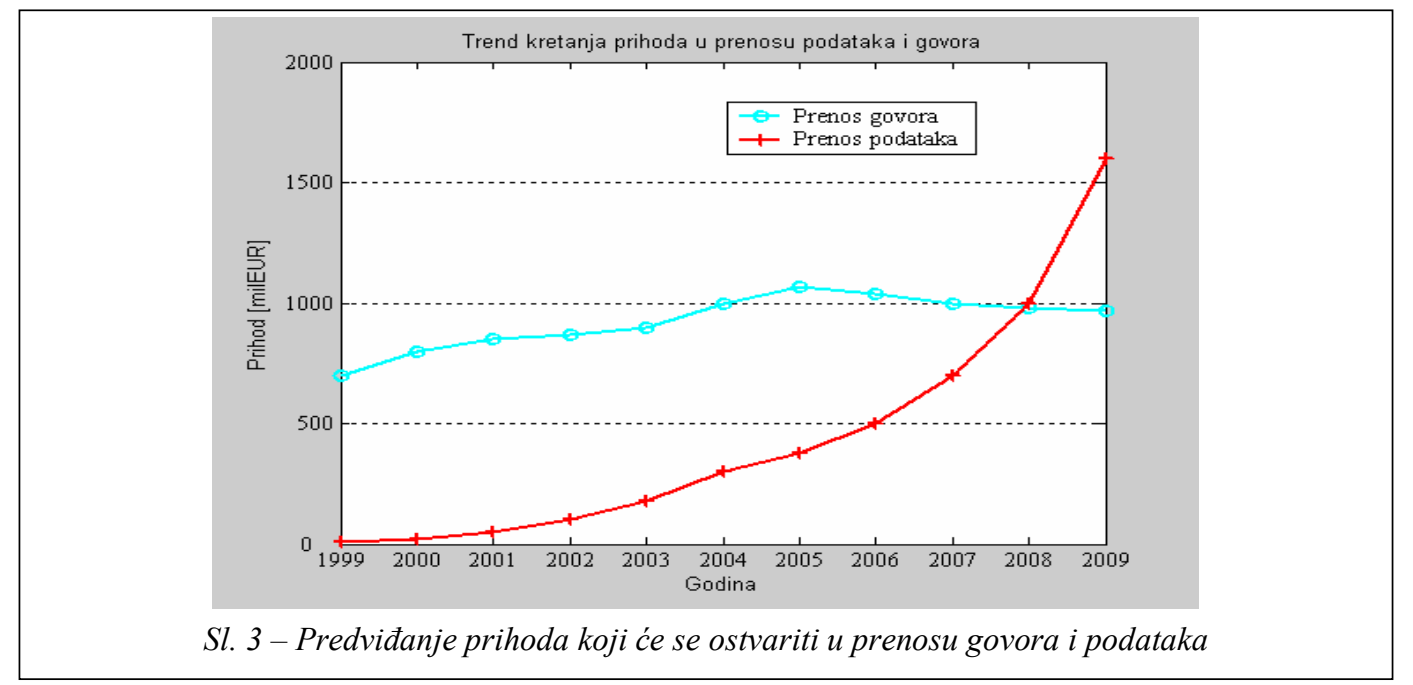

Istraživanja [2] koja se sprovode od 1999. godine govore $u$ prilog tome da godišnji porast prenosa podataka, uslovljen naglim razvojem paketske IP mreže, iznosi $40 \%$ u odnosu na rast u prenosu govornog saobraćaja od svega 5\% (slika 2).

Međutim, govorni saobraćaj će i dalje predstavljati znatan udeo u ukupnom prihodu telekomunikacionih operatera i zahtevati manje investicije u dalji razvoj [3], kako je prikazano na slici 3.

Prethodne tvrdnje ukazuju na to da je potrebno razvijati jedinstvenu mrežu koja će omogućiti istovremeni prenos govora $\mathrm{i}$ podataka. Najvažnija tehnologija koja se koristi za ovu svrhu je tehnologija za prenos govora preko interneta - VoIP (Voice over IP). Radi povezivanja klasičnih PSTN sa paketskim mrežama primenjuju se sledeći standardi: skup protokola H.323, protokol SIP (Session Inition Protocol), MGCP (Media Gateway Control Protocol) i protokol H.248 ili MEGACO.

\section{Arhitektura NGN}

Nove telekomunikacione tehnologije nalaziće sve veću primenu u izgradnji
NGN. Današnju transportnu tehnologiju IP preko ATM (Asynchronous Transport Mode), SDH (Synchronous Digital Hierarchy) i optike, u budućnosti će u potpunosti zameniti hijerarhijski IP direktno preko DWDM (Dense Wavelength Division Multiplexing). Takođe, zbog dobrih karakteristika u izgradnji i upravljanju mrežama sve češće će se koristiti MPLS (prikaz na slici 4).

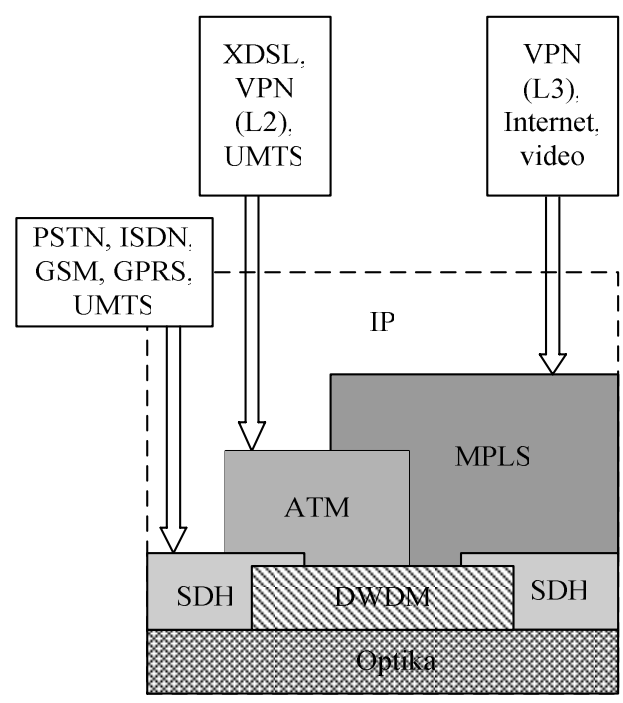

Sl. 4 -Hijerarhijski postavljeni slojevi u prenosnoj mreži 
Buduća generacija telekomunikacionih mreža baziraće se na mreži za prenos IP protokolom. Niži slojevi obuhvataju ATM i sinhronu optičku mrežu - SDH. Podaci se prenose preko SDH mreže, korišćenjem tehnologija WDM ili DWDM. U budućnosti, ATM i SDH neće biti potrebni, već će se IP direktno prenositi preko optike (DWDM).

Prvo će se formirati konvergentne mreže bazirane na principu IP/MPLS, koja bi obuhvatala najbolje karakteristike ATM mreže (po pitanju obezbeđenja zahtevanog nivoa QoS) i MPLS mreže (obezbeđenje funkcionisanja $\mathrm{u}$ različitim uslovima ometanja). Takva mreža mogla bi da predstavlja osnov za mreže buduće generacije, koje bi uz manja ulaganja mogle da obezbede sadašnje zahteve $u$ servisu za prenos govora i podataka, uz istovremeni prenos multimedijalnih sadržaja. Konvergentna mreža ima cilj da smanji broj potrebnih mrežnih elemenata za upravljanje i održavanje, a samim tim da smanji i kompleksnost sistema za podršku mreže. Na taj način smanjili bi se i ukupni troškovi u smislu kapitalnih i operativnih troškova. MPLS ima sve veću ulogu u obezbeđenju IP QoS. Iako je MPLS originalno namenjen da pojedno-

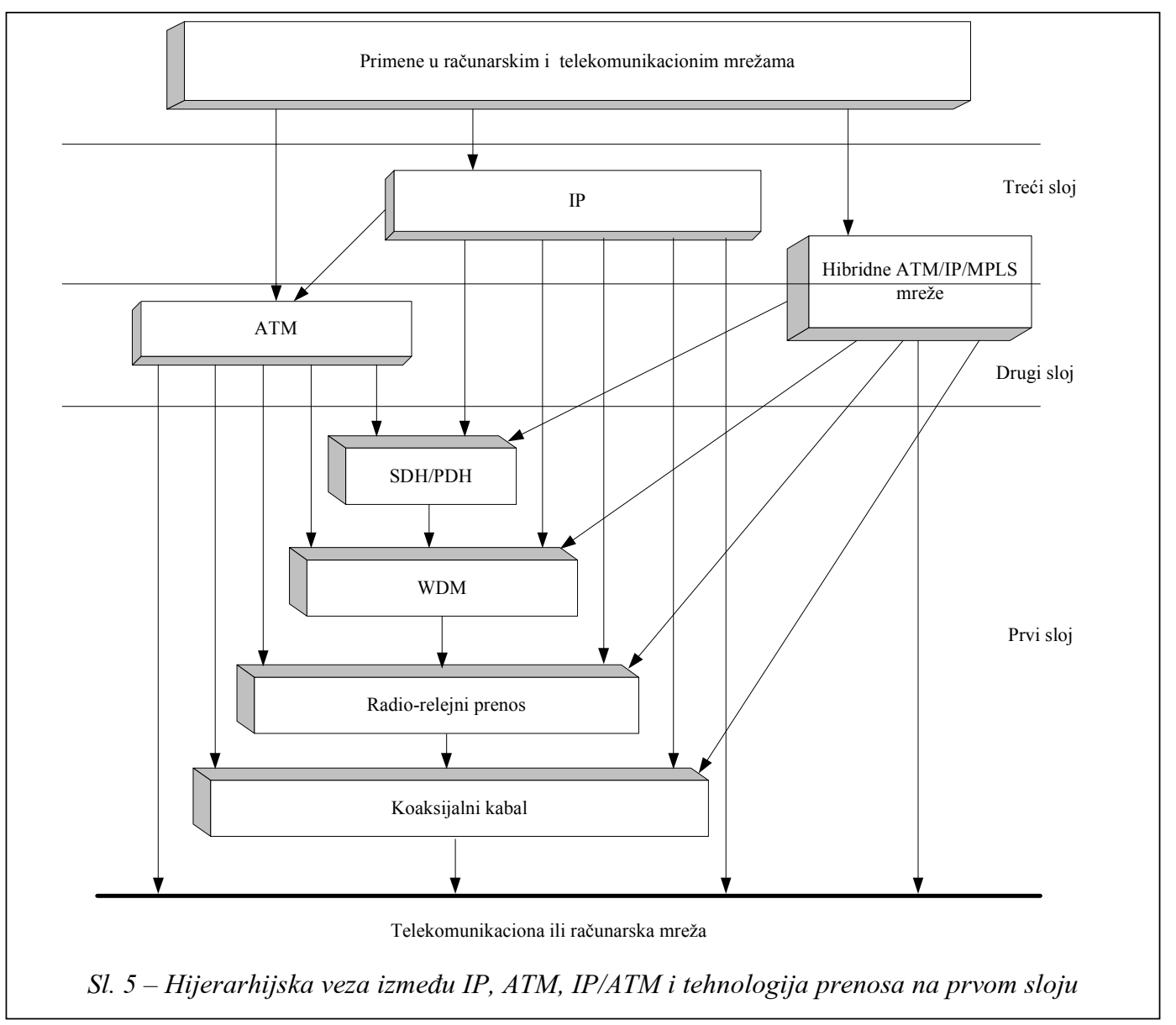


stavi usmeravanje saobraćaja na ruterima, neke osobine MPLS mogu da podržavaju QoS, što dovodi u pitanje neke od osnovnih atributa tradicionalnih tehnologija, kao što su ATM i Frame Relay. Međutim, postojeće usluge drugog nivoa (ATM, TDM) i dalje su veoma profitabilne telekomunikacione službe. Zbog toga će MPLS prvobitno evoluirati u transportnu mrežu najvišeg nivoa, zajedno sa ATM, da bi posle toga postao primarna tehnologija za omogućavanje multiservisa u pristupnim mrežama i mrežama sa ograničenim propusnim opsegom.

Trenutno, jedino ATM obezbeđuje potreban kvalitet usluga. Međutim, ekonomski je opravdanije rešenje za prenos IP saobraćaja direktno preko SDH, jer se ne javljaju troškovi u vezi sa ATM. Dalji razvoj kičmene mreže predstavljaće upotrebu MPLS.

Hijerarhija između ATM, IP/MPLS i hibridnog pristupa ATM/IP/MPLS prikazana je na slici 5 .

Na slici 6 prikazana je osnovna ideja realizacije mreže buduće generacije. Oblak predstavlja paketsku mrežu. Korisnici usluga mogu se priključiti direktno,

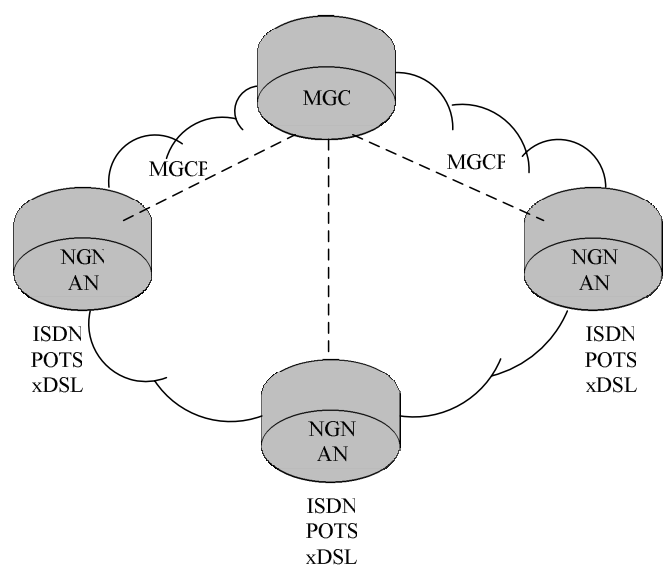

Sl. 6 - Primer osnovne realizacije NGN

ili preko pristupnih čvorišta NGN mreža, AN (Access Network). NGN AN ima ulogu da razdvoji govorni saobraćaj od paketskog i da ga pravilno usmeri. AN nadgleda kontrolor mrežnih prolaza MGC (Media Gateway Controller). Za kontrolu poziva, u NGN se koriste navedeni protokoli MGCP, H.323 i SIP.

Na slici 7 prikazana je osnovna arhitektura NGN, a zatim su opisani osnovni elementi mreže buduće generacije [4].

Mrežni prolaz medijuma (Media gateway) služi za prevođenje formata medi-

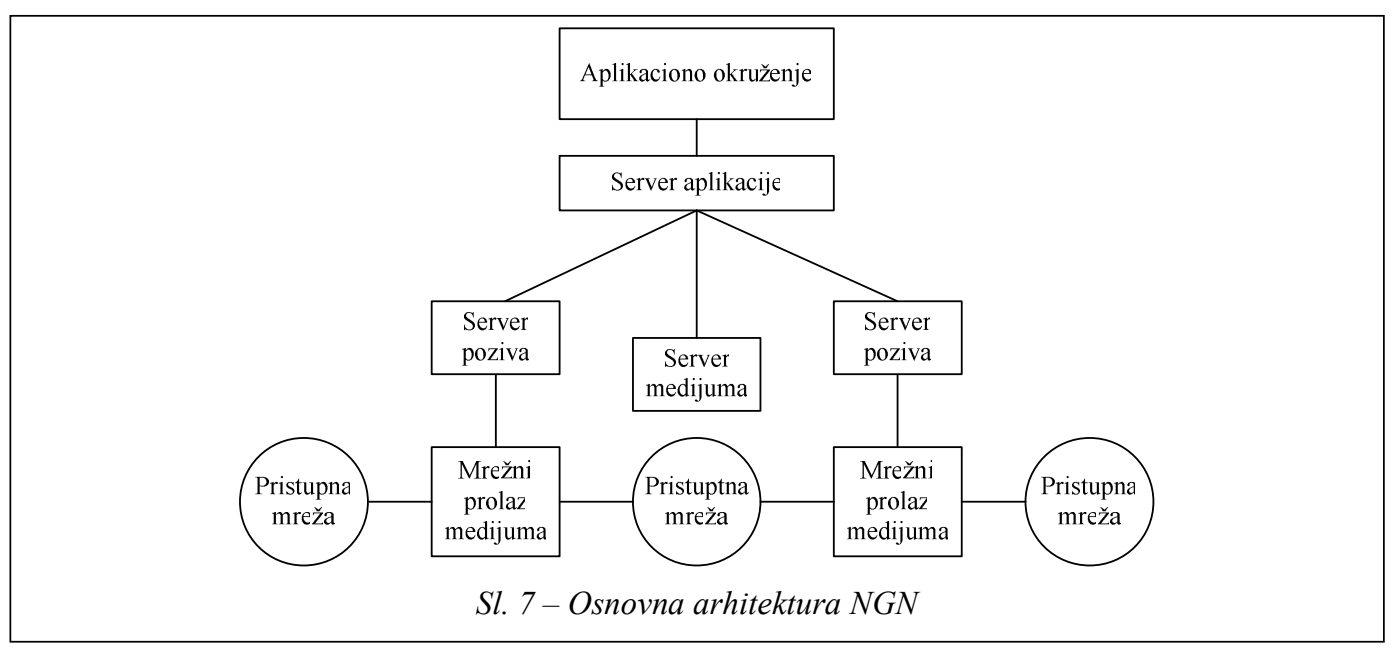


juma sa pristupne mreže u NGN paketsku mrežu. Osnovna uloga mrežnog prelaza jeste:

- prikupljanje podataka za naplatu i korisničke sisteme održavanja (evidencija poziva, statistička obrada);

- upozoravanje o abnormalnim događajima (zagušenje saobraćaja, prekid u vezi);

- unutrašnja komutacija (preslikavanje toka dolaznih paketa podataka u komutaciju kola);

- nadgledanje toka prenosa paketa podataka (kontrola saobraćajnih ugovora - PCR (Peak Cell Rate) u ATM mreži, odnosno definisanih klasa QoS za diffserv i RSVP (Resource reSerVation Protocol) u IP;

- podrška glavnim protokolima rutiranja OSPF (Open Shortest Path First), BGP (Border Gateway Protocol) i glavnim procedurama O\&M (Operation \& Maintenance);

- mogućnost integracije signalizacionih funkcija mrežnih prolaza.

Server poziva (Call Server) vrši upravljanje mrežnim prolazom medijuma u skladu sa primenjenom signalizacijom. Izvršava sledeće funkcije:

- podržava standardne protokole prema mrežnom prolazu, aplikacionom serveru i registraciju terminala (uključujući i AAA, Authentication, Authorization and Accounting);

- podržava rutiranje poziva u skladu sa planom numeracije (TRIP protokol) i procesima signalizacije poziva (SIP Session Inition Protocol H323, ISUP);

- obezbeđuje interfejs prema drugim serverima poziva (BICC - Bearier
Independent Call Control, SIP-T), prema prolazima medijuma (SIP, MGCP) i sa serverima medijuma;

- podržava signalizaciju SS7, uključujući ISUP i TCAP protokole za međusobni rad sa postojećim mrežama (PSTN).

Server medijuma (Media server) omogućava međusobnu komunikaciju korisnika i aplikacije preko telefonskog aparata (odgovor na poziv, izveštavanje i dr.). Njegove glavne funkcije su:

- funkcije resursa medijuma (prenos govora i snimanje, generisanje zvuka i detekcija, kompresija i kodovanje, prepoznavanje glasa);

- upravljačke funkcije koje obezbeđuju upravljanje resursima medijuma prema aplikacijama, bez obzira na upotrebljenu tehnologiju;

- interfejsi prema glavnim protokolima u NGN (Megaco, H.323, SIP, INAP).

Server aplikacije (Application server) obezbeđuje izvršenje usluge upravljanja serverom poziva. Osnovne funkcije su:

- interoperabilnost sa serverom poziva i upravljanje resursima preko standardnih protokola ili otvorenog API (Application Programming Interface) za podršku uslugama (rutiranje poziva i obračunavanje, snimanje poziva, nadgledanje autentičnosti, autorizacija, zatvorene korisničke grupe);

- obezbeđenje mehanizama podrške registracije (SIP registar, H.323 registracioni zahtevi);

- obezbeđenje usluge bezbednosti: šifrovanje, autentičnost, autorizacija, obezbeđenje sigurnog pristupa servisima $\mathrm{i} \mathrm{dr}$.

Na slici 8 predstavljen je način povezivanja javne telefonske mreže sa širokopojasnom mrežom. 


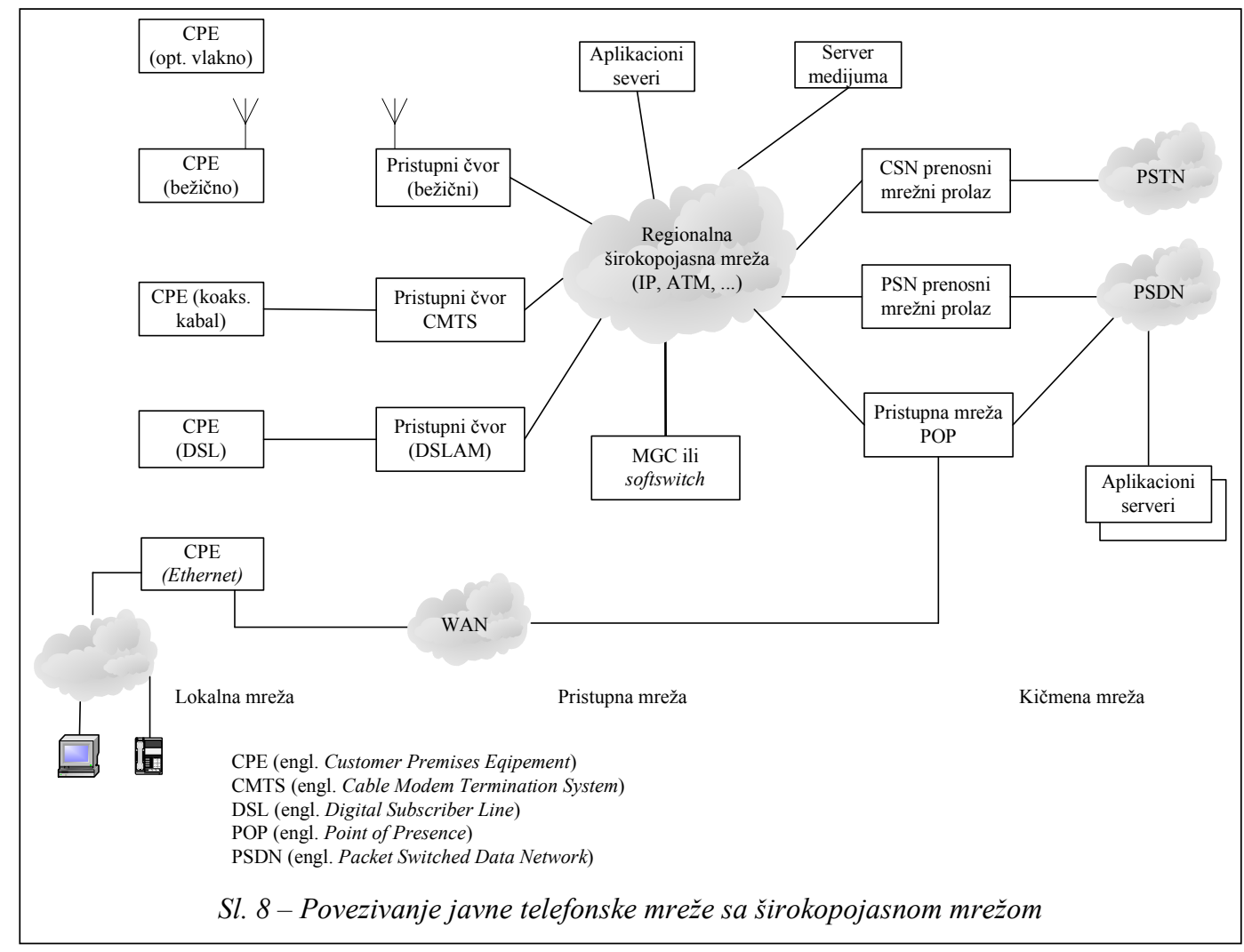

\section{Protokoli NGN}

Pred NGN se postavljaju strogi zahtevi za definisanje novih protokola koji bi podržali ovakve konvergentne mreže, odnosno moraju podržati uzajamni rad PSTN - internet mreža.

Osnovna klasifikacija protokola:

1. protokoli na relaciji server poziva $\leftrightarrow$ MG (H.248/Megaco, MGCP);

2. protokoli u istoj ravni peer-to-peer (SIP), i

3. protokoli između SS7 $\leftrightarrow$ NGN (SIGTRAN).

Da bi se obezbedio interoperabilan rad NGN na međunarodnom nivou potrebno je obezbediti odgovarajuću arhitekturu i protokole, QoS s kraja na kraj veze, upravljanje mrežom, definisati zakonsku regulativu i obezbediti zaštitu, odnosno bezbednost.

U NGN se nalaze sledeći protokoli:

- RTP (Real Time Protocol) - obezbeđuje prenos VoIP (Voice over IP) i koriste ga H.323, SIP, Megaco/H.248 i dr.;

- SDP (Session Description Protocol) - ostvaruje multimedijalni pristup i ima veliku rasprostranjenost;

- SIP (Session Inition Protocol) najčešće se koristi kao VoIP signalizacioni protokol i povezan je sa MMUSIC, SIPPING, SIMPLE WGs;

- ENUM (E.164 NUmber Mapping) - koristi se za preslikavanje E.164 telefonskih brojeva u URL adrese, kao i za SIP, HTTP, SMTP; 
- SIP-T (međusobni rad SIP\&ISUP) - definiše enkapsulaciju ISUP i SIP i vrši preslikavanje između SIP i ISUP polja;

- MGC (Media Gateway Protocol) - obuhvata protokole Megaco i MGCP i obezbeđuje prenos VoIP.

\section{Kvalitet usluga u mrežama za multimedijalnu komunikaciju}

Arhitekture buduće generacije mreža treba da omoguće kvalitet usluga $(\mathrm{Qu}-$ ality of Service - QoS) koji je potreban za nove službe i mrežne aplikacije, a posebno za multimedijalnu komunikaciju preko mreža koje koriste internet protokol (IP). Današnji internet, globalna računarska mreža, nastoji da posluži sav ponuđeni saobraćaj, što je moguće brže, sa ograničenjima koja su posledica tehničkih mogućnosti mreže. Pri tome ne postoje nikakve garancije koje bi se odnosile na propusni opseg, kašnjenje, varijaciju kašnjenja (džiter) i gubitak paketa.

Nivo performansi kvaliteta usluga (QoS) koji pruža internet spada u kategoriju „najboljeg mogućeg“ (best effort). Razlog dugog funkcionisanja ove mreže sa ovakvim nivoom kvaliteta jeste $u$ tome što najveći broj usluga i aplikacija koje se prenose internet protokolom (IP protokol) ima nizak prioritet, uzani propusni opseg za prenos podataka (telefonski kanal sa propusnim opsegom širine od 300 do $3400 \mathrm{~Hz}$ ) i velikom tolerancijom na kašnjenje i varijaciju kašnjenja. Danas ovakve performanse IP mreže ne zadovoljavaju potrebe.

Multimedijalna komunikacija $\mathrm{u}$ realnom vremenu (telefonija, video, grafi$\mathrm{ka}$, podaci) u mnogim internet aplikacija- ma i virtuelne privatne mreže, VPN (Virtual Private Network) zahtevaju garantovanu širinu propusnog opsega i stroge karakteristike za vremenske parametre (kašnjenje, džiter). Međutim, zbog eksponencijalnog porasta broja korisnika interneta dolazi do porasta verovatnoće „gomilanja“, što utiče na povećanje kašnjenja kroz mrežu i gubitaka paketa.

ITU-T preporuka Y.2001 (decembar 2004) definiše NGN kao paketski baziranu mrežu, koja omogućava različite telekomunikacione usluge i širokopojasni pristup nezavisan od primenjene tehnologije. NGN obezbeđuje nesmetan pristup korisnika mreži, koji se ogleda u pružanju usluga na bilo kom mestu (generalizovana mobilnost u radu).

Prenos multimedijalnog sadržaja obuhvata saobraćajne karakteristike sa različitih izvora (mirna i pokretna slika, prenos govora, tekstualnih podataka, datoteka i video prenos). Da bi se ostvario multimedijalni prenos moraju se definisati određeni zahtevi, kako bi se obezbedio zahtevani QoS: propusni opseg; dozvoljena varijacija kašnjenja (džiter); sinhronizacija i uspostavljanje prioriteta između aplikacija.

VPN omogućava korišćenje iste infrastrukture preko različitih mreža, tako što formira virtuelni tunel i koristi protokole zaštite i autentičnosti u prenosu kojima garantuje bezbednost, poverljivost $\mathrm{i}$ integritet podataka. Na ovaj način obezbeđuje se zahtevani QoS.

U ATM mrežama QoS je obezbeđen preko VC i VP. Združivanjem IP rutiranja i ATM komutatora omogućava se komunikacija velikog kapaciteta uz postizanje zahtevanog QoS. 
Ukoliko se pri prenosu ne zahteva eksplicitno QoS, prenos je moguć preko mreže na bazi IP, direktno preko optičkog vlakna, bez SDH ili nekog komutacionog protokola kakav je ATM. Međutim, u mrežama sa strogo zahtevanim QoS tehnologija ATM se mora upotrebiti.

\section{Zaštita informacija u NGN}

U mrežama nove generacije posebna pažnja posvećuje se analizi i definisanju sistema zaštite infrastrukture i informacija. Jedan celoviti sistem zaštite mogao bi se predstaviti u interakciji sledećih elemenata:

1) Preventivni - proučavanje i smanjenje osetljivosti: projektovanje; propisivanje zaštite.

2) Izvršenje zaštite - reagovanje na otkaze i ometanje: monitorisanje (nadgledanje); analiza; odziv na slučajan događaj.

3) Definisanje postupka zaštite evidencija radi zakonskog sprovođenja: procedure; pristupa; raspodela; postupka.

\section{Zaključak}

U radu su prikazane osnovne karakteristike i način realizacije arhitekture mreža buduće generacije. Opisane su mogućnosti projektovanja mreža koje bi objedinjavale istovremeni prenos govornog signala (uski propusni opseg, veoma ose-

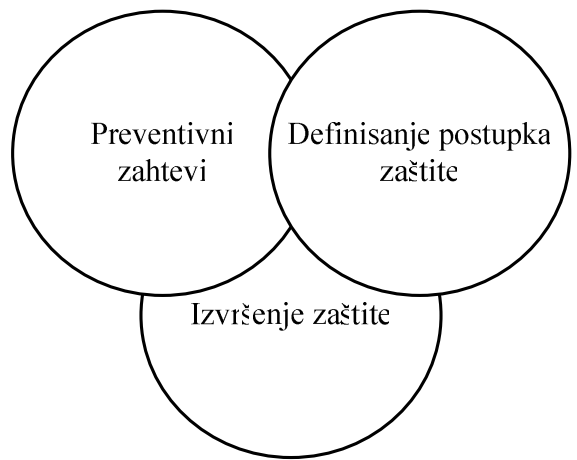

Sl. 9 - Interakcija između elemenata u sistemu zaštite mreža nove generacije

tljiv na kašnjenje, nije mnogo osetljiv na bitske greške i prenosi se kontinualno), video podataka (širi propusni opseg, srednje osetljivi na kašnjenje i greške, prenos se obavlja kontinualno) i prenos podataka (promenljivi propusni opseg, osetljivost na kašnjenje je varijabilna, dok je osetljivost na greške velika). Analizirana je postojeća infrastruktura kao platforma za izgradnju mreža buduće generacije, definisani su osnovni elementi mreže i opisane funkcije najvažnijih protokola.

\section{Literatura:}

[1] Glen, H. Ests: NGN: Preparing for Tomorrow's Services, Alcatel Telecommunications Review, 2-nd Quarter 2001, pp. 82-84.

[2] Stevenson, I., Pugh, E.: The Internet Telephony Report, Ovum, 1999.

[3] Communications International, 2000.

[4] Tzounakis, P.: Next Generation Networks, Network Operation Center, Aristotle University of Thessaloniki, 2002.

[5] Jevtović, M.: Multimedijalne telekomunikacije, Grafo-žig, Beograd, 2004. 